\title{
Comparative Studies on the Properties of LATS and TSH*
}

\author{
YuKIO OCHI AND LESLIE J. DEGROOT \\ Department of Internal Medicine, Kyoto Prefectural \\ University of Medicine, Kyoto and \\ Thvroid Study Unit, Department of \\ Medicine, University of Chicago, Chicago, Illinois
}

\section{Synopsis}

\begin{abstract}
LATS activity was neutralized by pretreatment of mice with anti-IgG in vivo. Simultaneous injection of epsilon-amino caproic acid and hydrocortisone does not inhibit LATS action. Human thyroid-microsomal fractions neutralize LATS activity and TSH activity. The decrease in activity of LATS and TSH caused by thyroid microsomes correlates positively. Calf thyroid microsomes are much less active than human thyroid microsomes in absorbing LATS activity. Deoxycholate and sonification solubilize the LATS neutralizing activity. No visible precipitate formed between these solubilized fraction and LATS-IgG, using the Ouchterlony agar diffusion method. LATS did not differ from TSH in heat stability, and partially heat denatured LATS still had a long acting type response. Dissociation of a small rapidly acting molecule from LATS could not be obtained in high molar $\mathrm{NaCl}$ solution. LATS-IgG fragments digested by proteolytic enzymes (papain, pepsin, trypsin, and ficin) had a prolonged response like LATS. However, these fragments, in the presence of cysteine, either gave the same response after $2 \mathrm{hr}$ and $8 \mathrm{hr}$, or gave a short acting response like TSH. The thyroid stimulating active site of the LATS active gamma globulin may be situated in Fab or Fab fragments having the antibody combining site. LATS did not stimulate the chicken thyroid, although TSH had this action. The proteolytic fractions of LATS-IgG also did not stimulate the chicken thyroid. No increase of gammaglobulin and/or IgG was found in some sera with a high LATS activity. Binding of LATS-IgG to mouse or human thyroid could not be visualized using the Coon's immunofluorescent method. These data support the concept that LATS is an IgG having a high specific activity of thyroid stimulating action.
\end{abstract}

Evidence has accumulated that Long Acting Thyroid Stimulator (LATS) is an immunoglobulin and that it plays an important role in the etiology of Graves' disease (Dorrington and Munro, 1966a; McKenzie, 1967). There are several reports of LATS crossing the placenta (McKenzie, 1964; Sunshine et al, 1965), which are compatible with LATS being an antibody. Further, gamma globulin antibody having thyroid stimulating activity is produced by immunization of rabbits with human thyroid cell fraction (Beall and Solo-

Received for publication March 20, 1970.

*Supported in part by USPHS Grants FR-88 and AM-13377 and American Cancer Society Grant P-298E mon, 1968; McKenzie, 1968). In previous experiments, we were unable to detect a "LATS" antigen by the passive cutaneous anaphylaxis technique or the indirect immunofluorescent method, and to this time, no clear immunological reaction has confirmed that an antigen for LATS is present in the components of the thyroid cell (Ochi and DeGroot, 1968).

Little is known of how LATS stimulates the thyroid gland. If the stimulatory action of LATS on the thyroid occurs following an immunologic conjugation with a thyroid antigen, the mode of action of LATS on the thyroid gland may differ from that of TSH. In this study, the properties of LATS were examined 
by several methods in comparison with the properties of TSH.

\section{Materials and Methods}

\section{Antisera preparations}

Rabbit antisera to human IgG were produced by immunization with IgG and Freund's adjuvant. Antibody titers were determined by the IgG sensitized red cell technique and antibody titers of more than $1 / 40,000$ were obtained. Rabbit IgG fraction was separated by DEAE-cellulose chromatography as previously described (Ochi and DeGroot, 1968). Rabbit antibody specific for $\gamma$ chain of human IgG was made from the rabbit anti-IgG preparation by absorption with human gamma globulin light chains.

\section{Bioassay of LATS and TSH}

LATS assay was performed by the method of McKenzie. Technical details of the LATS assay were described previously (Ochi and DeGroot, 1968). Usually all assay materials were injected i. v. in a volume of $0.5 \mathrm{ml}$. Changes in the blood radioactivity were determined $2 \mathrm{hr}, 8 \mathrm{hr}$, and, in some experiments, $24 \mathrm{hr}$ after the injection of test samples.

\section{Neutralizing Experiments}

The isolation of immunochemically pure LATS -IgG fraction from sera having LATS response was previously described. Three $\mathrm{mg}$ of this material produced a $1000 \%$ response after $8 \mathrm{hr}$.

Various amounts of anti- $\gamma$-chain were injected i.p. in the assay mice, and then $30 \mathrm{~min}$ later LATS-IgG fractions were injected i.v. Control animals were injected i.p. with saline instead of antibodies.

\section{Effect of Immunosuppressive Drugs on LATS Activity}

Saline solution of Epsilon-Aminocaproic Acid (EACA) and hydrocortisone were injected simultaneously with LATS-IgG. In every experiment, TSH (Armour, Thytropar) was used as the control.

\section{Tissue Preparations}

Human thyroid tissue sub-cellular fractions were prepared as previously reported. In some studies thyroid microsomes were incubated for $3 \mathrm{hr}$ at $4{ }^{\circ} \mathrm{C}$ with $0.5 \%$ sodium deoxycholate and a soluble microsome supernatant fraction was obtained after centrifugation at $100,000 \times \mathrm{g}$ for one $\mathrm{hr}$. In other studies, microsomal fractions in saline were solubilized by sonification (1.1 amps for $45 \mathrm{sec}$, Sonic oscillator, Raytheon Manufacturing Co.). Soluble microsome supernatant fraction was fractionated by the salting out method using potassium phosphate buffer, $\mathrm{pH}$ 6.6. Calf thyroid tissue was also fractionated by the method described above.

\section{Absorption of LATS Activity By Thyroid Cell Fractions.}

LATS-IgG $(3 \mathrm{mg})$ or TSH $(3 \mathrm{mU})$ was incubated with the subcellular fractions of thyroid. Amounts of 5 to $10 \mathrm{mg}$ tissue protein (human) in $1 \mathrm{~m} l$ or 10 to 50 $\mathrm{mg}$ tissue (calf) in $1.5 \mathrm{~m} l$ of $0.15 \mathrm{M}$ phosphate buffer, $\mathrm{pH} 7.2$, were incubated at $37^{\circ} \mathrm{C}$ for one hour by shaking and then stored overnight at $5^{\circ} \mathrm{C}$. The material was then centrifuged at $800 \times \mathrm{g}$ for 15 min (nuclear fraction), $8,000 \times \mathrm{g}$ for $20 \mathrm{~min}$ (mitochondrial fraction) and $100,000 \times \mathrm{g}$ for one $\mathrm{hr}$ (microsomal fraction). After removal of the precipitate by centrifugation, the LATS or TSH activity of the supernatant fraction was assayed. The relation between the assay response and the injected amounts of the thyroid stimulator showed almost straight line under a $800 \%$ response in the McKenzie assay. In this absorption experiment, the assay was performed within a $800 \%$ response usually.

\section{Heat Stability of LATS or TSH}

LATS-IgG $(3 \mathrm{mg})$ or TSH $(3 \mathrm{mU})$ in $1 \mathrm{~m} l$ of 0.15 $M$ phosphate buffer, $\mathrm{pH} 7.2$ was incubated for $30 \mathrm{~min}$ at $56^{\circ} \mathrm{C}, 2 \mathrm{hr}$ at $56^{\circ} \mathrm{C}$ and $10 \mathrm{~min}$ at $70^{\circ} \mathrm{C}$ in a water bath. The solution was centrifuged at 3,000 rpm for $15 \mathrm{~min}$ and the supernatant was removed for assay.

\section{Possible Dissociation of LATS -IgG Complex By $2 \mathrm{M} \mathrm{NaCl}$}

To examine the possibility that LATS is an active molecule firmly bound to gamma globulin, LATSIgG fractions were treated with $2 \mathrm{M} \mathrm{NaCl}$ at $\mathrm{pH} 3.5$ (acetate buffer) or pH 7.4 (phosphate buffer) in $2 \mathrm{~m} l$ at various temperatures. After incubation, LATS-IgG fractions were dialyzed with $0.15 M$ phosphate buffer, $\mathrm{pH} 7.2$ before assay.

\section{Proteolytic Digestion of LATS-IgG}

Enzymatic cleavage using crystalline papain was performed according to the method of Porter as modified by Putman et al. (1966). LATS-IgG fraction (100 $\mathrm{mg}$ ) was incubated with proteolytic enzymes such as papain, pepsin, trypsin, and ficin at concentrations of $20 \mathrm{mg}$ LATS-IgG protein $/ \mathrm{m} l$, with enzyme to protein ratio of $1: 100$, in the presence or absence of $0.01 M$ cysteine. In each case, the appropriate $0.1 M$ buffer was chosen and incubation was performed for $18 \mathrm{hr}$ at $37^{\circ} \mathrm{C}$

Chromatographic separation of the papain digests, on a $2 \times 30 \mathrm{~cm}$ column of DEAE-cellulose, was carried out by elution with a gradient of $0.02 M$ to $0.3 M$ Tris-HCl buffer, pH 8.0 (Fagelman, 1966). The 
Fc fragment obtained had a slight contamination with Fab fragment.

The $\mathrm{F}\left(\mathrm{ab}^{\prime}\right)_{2}$ fragments $(5 \mathrm{~S})$ from the peptic digest of LATS-IgG were obtained according to the procedure described by Mandy and Nisonoff (1963). LATS-IgG fraction in $0.1 \mathrm{M}$ sodium acetate, $\mathrm{pH} 4.1$, was digested with pepsin ( $1 \%$ by weight of protein) for $20 \mathrm{hr}$ at $37^{\circ} \mathrm{C}$. A small amount of precipitate was removed by centrifugation after digestion, then $\mathrm{pH}$ was adjusted to $\mathrm{pH} 8.0$, and sodium sulfate was added to a final concentration of $18 \mathrm{~g}$ per $100 \mathrm{ml}$. The heavy precipitate was separated by centrifugation, dissolved in water, and dialyzed against cold saline overnight.

For the preparation of $\mathrm{F} \mathrm{ab}^{\prime}$ fragment of LATS$\mathrm{IgG}$, the $\mathrm{F}\left(\mathrm{ab}^{\prime}\right)_{2}$ in $0.1 \mathrm{M}$ sodium acetate, $\mathrm{pH} 5.0$, was reduced with cysteine at a final concentration of 0.01 $M$ at $37^{\circ} \mathrm{C}$ for one $\mathrm{hr}$.

\section{Bioassay of Thyroid Stimulating Substance Using Chickens}

Bioassay for TSH activity was performed by measuring the release of radioiodine from the thyroid gland of thyroxine-treated chicks. One day old chicks (Silver Strain, Hall Brother Hatchery, Inc., Conn.) fed chicken mash, (Old Mother Hubbard, Gloucester, Mass.) were injected i.p. with ${ }^{125} \mathrm{I}(15 \mu \mathrm{C} /$ animal $)$ to label the thyroid gland, and one day later thyroxine was given in the drinking water $(5 \mu \mathrm{g} / \mathrm{m} l)$ to depress endogenous TSH secretion for three days.

Blood $(0.1 \mathrm{~m} l)$ was obtained from the wing vein, and assay samples were injected i.p. in a volume of 0.5 $\mathrm{ml} .2 \mathrm{hr}, 8 \mathrm{hr}$, and $24 \mathrm{hr}$ after the injection of the test sample blood was taken. Changes in the blood radioactivity were expressed at a percentage of the initial value.

\section{Antibody Titer Determination}

After removal of complement by heating at $56^{\circ} \mathrm{C}$ for $30 \mathrm{~min}$, anti-thyroglobulin titers in serum were estimated by the tanned red cell technique (Burroughs-
Wellcome Company, New York). Antibodies to cytoplasm and colloid were detected using the indirect immunofluorescent technique (Ochi and DeGroot, 1968). Double diffusion in agar technique was performed by the method of Ouchterlony (1958). Diffusion was carried out for a period of $24 \mathrm{hr}$.

Human IgG estimation was carried out by the agar gel diffusion method using Immunoplates (Behringwerke). Diluted sera were placed in the wells of the agar and the diameter of the precipitation ring formed in $24 \mathrm{hr}$ was calculated. Determination of serum gamma globulin fraction by electrophoresis was performed in Boston Medical Laboratory, Waltham, Massachusetts.

\section{Results}

\section{Inhibition of LATS Activity by Pre- treatment With Anti-IgG of Assay Mice}

As shown in Table 1, the activity of $2.5 \mathrm{mg}$ of LATS-IgG was decreased by pretreatment with 25 or $50 \mathrm{mg}$ of anti- $\gamma$-chain. When injection of LATS-IgG followed pretreatment with $100 \mathrm{mg}$ of anti- $\gamma$-chain, all assay mice died within two hr. This may be due to the occurrence of a severe antigen-antibody reaction. Anti-IgG did not decrease the stimulatory action of TSH.

\section{Difference of Assay Response of TSH and LATS}

In the McKenzie assay, $2 \mathrm{mU}$ TSH caused a maximal radioactivity increase after $2 \mathrm{hr}$, but LATS after $8 \mathrm{hr}$. When large amounts of TSH (4 $\mathrm{mU}$ or more) were injected i. v., the assay

Table 1. Inhibition of LATS activity by antibody to $\gamma$-chain of IgG

\begin{tabular}{clclcccc}
\hline \hline Group & Pretreatment & Amounts & Injection & Amounts & \multicolumn{2}{c}{ Assay response (\%) } & $\begin{array}{c}\text { Decrease in } \\
\text { thyroid stimulation } \\
(\%)\end{array}$ \\
\hline 1 & Saline & & & $2 \mathrm{hr}$ & $8 \mathrm{hr}$ & \\
2 & Anti- $\gamma$-chain & $25 \mathrm{mg}$ & LATS-IgG & $2.5 \mathrm{mg}$ & $514 \pm 27$ & $1091 \pm 161$ & \\
3 & Anti- $\gamma$-chain & $50 \mathrm{mg}$ & LATS-IgG & $2.5 \mathrm{mg}$ & $344 \pm 65$ & $607 \pm 77$ & 42 (at $8 \mathrm{hr})$ \\
4 & Saline & & Armour TSH & $4.5 \mathrm{mg}$ & $292 \pm 38$ & $380 \pm 68$ & 72 (at $8 \mathrm{hr})$ \\
5 & Anti- $\gamma$-chain & $50 \mathrm{mg}$ & Armour TSH & $4 \mathrm{mU}$ & $508 \pm 54$ & $752 \pm 55$ & NS \\
\hline
\end{tabular}

Mice were injected i.p. with anti $\gamma$-chain antibody and then $30 \mathrm{~min}$ later LATS or TSH was injected i.v. All values are shown as mean \pm standard deviation for group of four animals.

NS: Not statistically significant. $p>0.05$. 


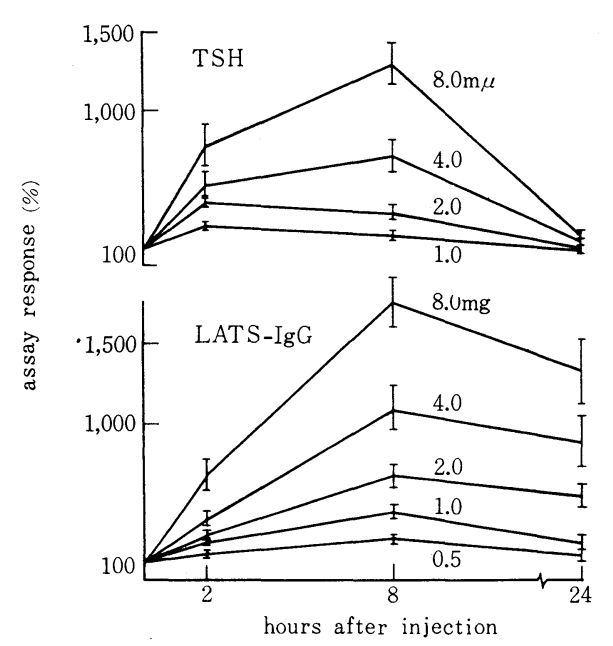

Fig. 1. Difference between LATS and TSH in assay response. Various amounts of TSH (Armour, Thytropar) and LATS-IgG were assayed.

response became like LATS $(2 \mathrm{hr}<8 \mathrm{hr})$. This response significantly decreased to less than $20 \%$ of the $8 \mathrm{hr}$ level after $24 \mathrm{hr}$. LATSIgG always gave an $8 \mathrm{hr}$ response higher than at $2 \mathrm{hr}$, even with small doses, and more than $60 \%$ of the $8 \mathrm{hr}$ response remained after $24 \mathrm{hr}$ (Fig. 1).

\section{Simultaneous Injection of LATS With Immunosuppressive Drugs}

EACA (100 mg) and hydrocortisone ( $2 \mathrm{mg}$ ) did not inhibit the assay response to LATS or TSH (Table 2).

\section{Absorption of LATS By Thyroid Cell Fractions}

Nuclear, mitochondrial and supernatant fractions absorbed LATS activity during in vitro incubations (Fig. 2). The microsomal fraction was especially effective in absorbing LATS. Microsomal fraction also absorbed TSH.

The ability of thyroid microsomes to absorb LATS and TSH was compared, as shown in Figure 3. The decrease in activity of LATS and TSH was positively correlated $(r=0.817)$.

Thyroid microsome fraction absorbing LATS was solubilized by sodium deoxycholate solution. The absorbing component was largely in the soluble fraction. When the microsome fraction was solubilized by sonification, absorption was evident in the supernatant and precipitate. These results differ, for unknown reasons, from those in the report of Beall and Solomon (1966b), who could not solubilize the LATS inhibiting factor with deoxycholate or

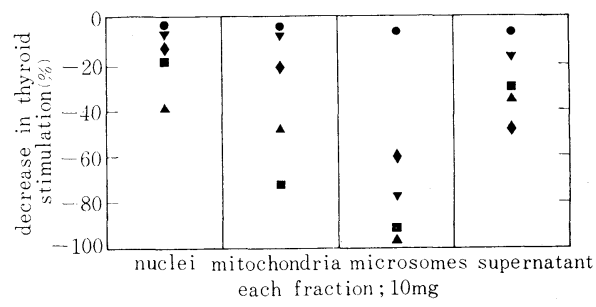

Fig. 2. Inhibition of LATS activity by thyroid cell fractions. Each symbol shows the fractions obtained from the same thyroid.

Table 2. Effect of EACA and hydrocortisone on LATS activity following simultaneous injection

\begin{tabular}{lrlrrrr}
\hline \hline Test material & Amount & $\begin{array}{l}\text { Simultaneous } \\
\text { injection }\end{array}$ & Amoung & \multicolumn{2}{c}{ Assay response (\%) } & \multicolumn{2}{c}{ P Value } \\
from control
\end{tabular}

All values are shown as mean \pm standard deviation.

NS: Not statistically significant. $p>0.05$

EACA: Epsilon-Amino Caproic Acid. 
sonication. Deoxycholate solubilized microsomal fraction was salted out by $45 \%$ saturated potassium phosphate buffer. The absorbing ability was largely in the precipitate fraction (Table 3). No visible precipitate was observed in Ouchterlony agar diffusion of LATS-IgG and these solubilized microsome fractions.

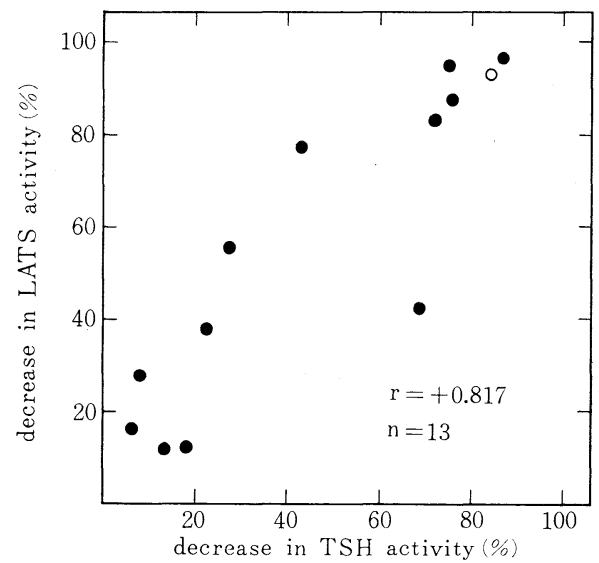

Fig. 3. Correlation of the decrease in activity of LATS and TSH following incubation with human thyroid microsomes. Closed circles represent the results using untreated microsomes, and open circles represent the results using a fraction solubilized by deoxycholate treatment. Each assay animal received $3 \mathrm{mg}$ LATS-IgG.
The ability of calf thyroid fractions to absorb LATS-IgG was examined. The level of LATS absorption was highest with the microsomal fraction, and low with the other fractions. Absorption required $40 \mathrm{mg}$ of the microsomal fraction protein. (Fig. 4)

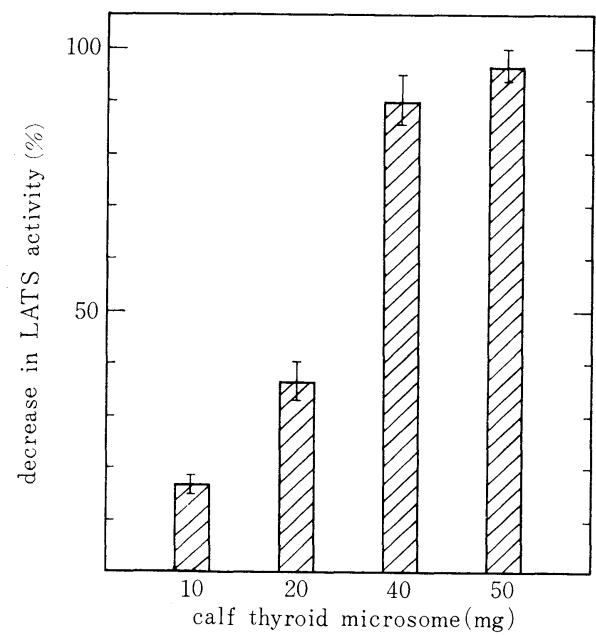

Fig. 4. Inhibition of LATS activity by calf thyroid microsomes. Forty $\mathrm{mg}$ of microsomes inhibited almost completely the LATS activity. Each assay animal received $3 \mathrm{mg}$ LATS-IgG.

Table 3. Inhibition of LATS activity by fractions solubilized from thyroid microsomes

\begin{tabular}{lcc}
\hline \multicolumn{1}{c}{ Thyroid Microsome Preparation } & $\begin{array}{c}\text { Microsomal } \\
\text { protein }\end{array}$ & $\begin{array}{c}\text { Decrease in } \\
\text { LATS activity (\%) }\end{array}$ \\
\hline Suspended in saline & $5 \mathrm{mg}$ & 81 \\
Suspended in saline & $10 \mathrm{mg}$ & 97 \\
Deoxycholate treated & & \\
$100,000 \times$ g supernatant (solubilized) & $6 \mathrm{mg}$ & 81 \\
$100,000 \times$ g precipitate (nonsolubilized) & $4 \mathrm{mg}$ & 50 \\
Salting out of deoxycholate solubilized preparation & & \\
Supernatant with $45 \%$ saturated potassium phosphate buffer & $12 \mathrm{mg}$ & 10 \\
Precipitate from $45 \%$ saturated potassium phosphate buffer & $3.5 \mathrm{mg}$ & 55 \\
Sonicated microsomes (after sonication) & $10 \mathrm{mg}$ & 95 \\
$100,000 \times$ g supernatant & $10 \mathrm{mg}$ & 61 \\
$100,000 \times$ g precipitate & $10 \mathrm{mg}$ & 84 \\
\hline
\end{tabular}

In each assay, LATS-IgG $(3 \mathrm{mg})$ was pre-incubated with the microsomal preparation as discussed in Methods. Four animals were used per group, and experimental results are as expressed as a present reduction from the control value obtained with untreated LATS. 


\section{Heat Stability of LATS and TSH}

Figure 5 shows the reduction in potency after heat treatment. There was no loss of LATS activity after $30 \mathrm{~min}$ at $56^{\circ}$, and slight loss after $2 \mathrm{hr}$ at $56^{\circ}$. More than $70 \%$ of activity was lost by treatment at $70^{\circ}$ for $10 \mathrm{~min}$. A similar loss of activity was observed as for $\mathrm{TSH}$. In spite of heat denaturation at $70^{\circ} \mathrm{C}$ of the LATS molecule, the assay response of "Long Acting Type" ( $8 \mathrm{hr}>2 \mathrm{hr})$ did not change to short acting type ( $2 \mathrm{hr}>8 \mathrm{hr})$.

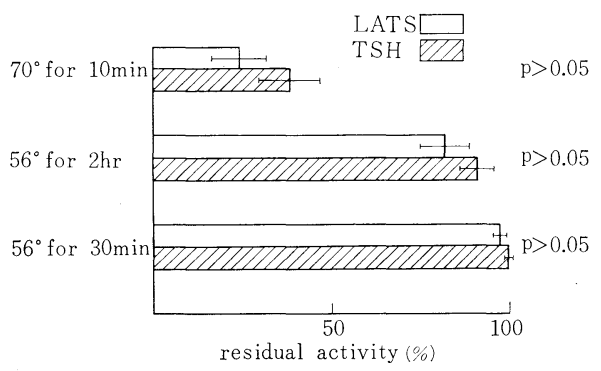

Fig. 5. Heat stability of LATS and TSH. After heating at various conditions, the loss of activity of LATS-IgG $(3 \mathrm{mg})$ and TSH $(3 \mathrm{mU})$ were compared. No statistically significant difference between LATS and TSH was observed in these treatments.
6. Possible Dissociation of LATS-IgG Complex By High Ionic Strength Solution

Treatment of LATS-IgG with $2 M \mathrm{NaCl}$ at acidic and neutral $\mathrm{pH}$ did not alter the time course of response. LATS activity in the samples incubated at $56^{\circ}$ was decreased to some degree. It was not possible to dissociate an active small fragment from IgG and thus obtain a "short acting" response. (Table 4)

\section{Changes of LATS Activity After Treat- ment With Proteolytic Enzymes}

LATS activity was significantly decreased, but the time course of response did not change after digestion of LATS-IgG with papain, pepsin and trypsin. By treatment with proteolytic enzymes plus cysteine, digested LATSIgG usually showed the same response in $2 \mathrm{hr}$ and $8 \mathrm{hr}$, or became "short acting," and its thyroid stimulating activity was significantly lost (about 80\%).

$\mathrm{F}(\mathrm{ab})_{2}$ fragment separated from papain digestion or $F\left(a b^{\prime}\right)_{2}$ fragment from pepsin digestion showed a long acting response. However, Fab and $\mathrm{Fab}^{\prime}$ fragments obtained by cysteine reduction showed a short acting type response like TSH. Fc fragment obtained

Table 4. LATS activity after the treatment with $2 M \mathrm{NaCl}$ solution

\begin{tabular}{|c|c|c|c|}
\hline \multirow{2}{*}{ Exp. No. } & \multirow{2}{*}{ Treatment } & \multicolumn{2}{|c|}{ Assay response $(\%)$} \\
\hline & & $2 \mathrm{hr}$ & $8 \mathrm{hr}$ \\
\hline \multirow[t]{5}{*}{1} & None & $473 \pm 67$ & $1280 \pm 120$ \\
\hline & $2 M \mathrm{Nacl}, 37^{\circ}$ for $2 \mathrm{hr}$ at $\mathrm{pH} 7.4$ & $493 \pm 48$ & $1330 \pm 70$ \\
\hline & $2 M \mathrm{NaCl}, 56^{\circ}$ for $30 \mathrm{~min}$ at $\mathrm{pH} 7.4$ & $235 \pm 29$ & $830 \pm 150$ \\
\hline & $2 M \mathrm{NaCl}, 37^{\circ}$ for $2 \mathrm{hr}$ at $\mathrm{pH} 3.5$ & $352 \pm 20$ & $1133 \pm 113$ \\
\hline & $2 M \mathrm{NaCl}, 56^{\circ}$ for $30 \mathrm{~min}$ at $\mathrm{pH} 3.5$ & $199 \pm 32$ & $652 \pm 88$ \\
\hline \multirow[t]{6}{*}{2} & $0.15 \mathrm{M} \mathrm{NaCl}, 20^{\circ}$ for $12 \mathrm{hr}$ at $\mathrm{pH} 7.4$ & $381 \pm 49$ & $817 \pm 94$ \\
\hline & $2 M \mathrm{NaCl}, 20^{\circ}$ for $12 \mathrm{hr}$ at $\mathrm{pH} 7.4$ & $422 \pm 63$ & $824 \pm 73$ \\
\hline & $2 M \mathrm{NaCl}, 56^{\circ}$ for $30 \mathrm{~min}$ at $\mathrm{pH} 7.4$ & $401 \pm 37$ & $813 \pm 67$ \\
\hline & $0.15 \mathrm{M} \mathrm{NaCl}, 20^{\circ}$ for $12 \mathrm{hr}$ at $\mathrm{pH} 3.5$ & $193 \pm 27$ & $502 \pm 37$ \\
\hline & $2 \mathrm{M} \mathrm{NaCl}, 20^{\circ}$ for $12 \mathrm{hr}$ at $\mathrm{pH} 3.5$ & $137 \pm 14$ & $383 \pm 27$ \\
\hline & $2 M \mathrm{NaCl}, 56^{\circ}$ for $30 \mathrm{~min}$ at $\mathrm{pH} 3.5$ & $121 \pm 5$ & $246 \pm 29$ \\
\hline
\end{tabular}

Exp. (1): After the treatment all assay samples were dialyzed against saline overnight at $5^{\circ}$. Each assay animal received $4 \mathrm{mg}$ LATS-IgG.

Exp. (2): After the treatment all assay samples were adjusted to neutral $\mathrm{pH}$ by phosphate buffer. Each animal received $2.5 \mathrm{mg}$ LATS-IgG.

All values are shown as mean \pm standard deviation. 
Table 5. Effect of proteolysis on LATS activity

\begin{tabular}{|c|c|c|c|c|}
\hline \multirow{2}{*}{$\begin{array}{c}\text { Test } \\
\text { Material }\end{array}$} & \multirow{2}{*}{$\underset{(\mathrm{mg})}{\text { Amount }}$} & \multirow{2}{*}{ Treatment } & \multicolumn{2}{|c|}{ Assay response $(\%)$} \\
\hline & & & $2 \mathrm{hr}$ & $8 \mathrm{hr}$ \\
\hline \multirow[t]{8}{*}{ LATS-IgG } & 3 & None & $388 \pm 43$ & $870 \pm 88$ \\
\hline & 3 & Papain & $320 \pm 22$ & $458 \pm 40$ \\
\hline & 3 & Papain + Cysteine & $248 \pm 18$ & $213 \pm 14$ \\
\hline & 3 & Pepsin & $412 \pm 31$ & $540 \pm 24$ \\
\hline & 3 & Pepsin + Cysteine & $402 \pm 27$ & $270 \pm 29$ \\
\hline & 3 & Trypsin & $380 \pm 29$ & $738 \pm 69$ \\
\hline & 3 & Trypsin + Cysteine & $369 \pm 19$ & $360 \pm 42$ \\
\hline & 3 & Ficin + Cysteine & $467 \pm 48$ & $362 \pm 45$ \\
\hline $\mathrm{F}(\mathrm{ab})_{2}$ fragment & 5 & & $360 \pm 41$ & $450 \pm 58$ \\
\hline $\mathrm{F}$ ab fragment & 5 & & $418 \pm 68$ & $242 \pm 42$ \\
\hline Fc fragment & 5 & & $103 \pm 18$ & $112 \pm 19$ \\
\hline $\mathrm{F}\left(\mathrm{ab}^{\prime}\right)_{2}$ fragment & 6 & & $388 \pm 46$ & $587 \pm 102$ \\
\hline $\mathrm{F} a b^{\prime}$ fragment & 6 & & $406 \pm 52$ & $267 \pm 80$ \\
\hline
\end{tabular}

from papain digestion did not show thyroid stimulating activity (Table 5).

\section{Bioassay of Thyroid Stimulating Ac- tivity In Chicks}

The response of the chick to TSH was less sensitive than the bioassay in mice. In chicks a minimal response required approximately $1-2$ $\mathrm{mU}$, in mice $0.2-0.4 \mathrm{mU}$ was needed. In chicks, TSH (bovine) usually gave a maximal response after $2 \mathrm{hr}$ and then gradually decreased. After injection of large doses of TSH (more than 10 $\mathrm{mU}$ ), the assay response became prolonged ( 8 $\mathrm{hr}>2 \mathrm{hr}$.

In chicks, human and bovine TSH had a strong stimulatory effect, but LATS did not stimulate.

LATS-IgG fractions, prepared by papain and pepsin digestion were examined in the chick bioassay. No thyroid stimulating activity was found in digests prepared with the presence or absence of cysteine (Table 6).

\section{The Level of Serum Gamma Globulin} In LATS Positive Sera (Table 7)

Content of gamma globulin in several LATS positive sera that had more than $1000 \%$ response after $8 \mathrm{hr}$ in the assay were examined. Serum total globulin levels were not increased. Four out of nine had small elevations of $\gamma$ globulin and two out of these had minimal elevation of $\mathrm{IgG}$, determined by immunoprecipitation. There was no correlation between the globulin levels and LATS, or thyroid antibodies.

\section{Immunofluorescent Localization of LATS}

An attempt was made to identify LATS in animal thyroid tissue after in vivo or in vitro exposure to LATS-IgG.

LATS-IgG (5 mg), which produced greater than a $1000 \%$ response in the bioassay, and inactive human IgG, were administered intravenously to mice. Recipient mice were killed after 2 and $8 \mathrm{hr}$, the thyroids were dissected out, and then frozen on solid $\mathrm{CO}_{2}$. The tissue was used in the direct Coon's technique, after staining with fluorescein conjugated rabbit anti-human IgG. Thyroid tissue was processed with and without fixation in ethanol. $\mathrm{IgG}$ was detected in vessels and interstitial areas after $2 \mathrm{hr}$ and $8 \mathrm{hr}$, and later faint fluorescence was present over the thyroid cells and colloid. There was no difference in the pattern obtained with LATS-IgG or nonspecific IgG.

A study was made of the pattern of fluorescence obtained using either guinea pig or human thyroid tissue antigen, and sera from thyroid patients, in the indirect Coon's technique. Six sera were studied in each combina- 
tion of the following categories: Strong LATS positive or negative, and strong cytoplasmic antibody positive or negative. Thyroid tissue was prepared with or without ethanol fixation. It was impossible to differentiate LATS positive from LATS negative sera.

Table 6. Failure of LATS and its digested fragments to stimulate the chick Thyroid*

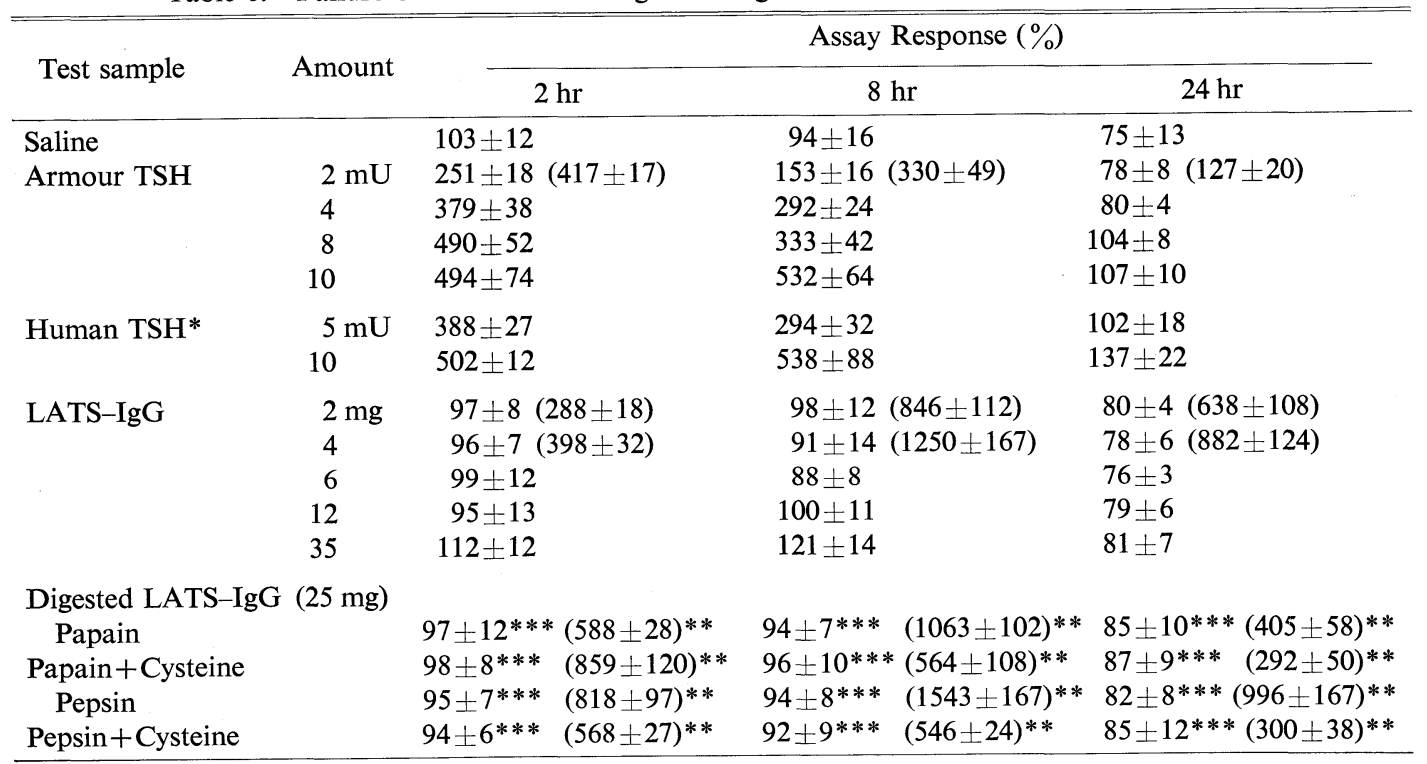

The values in parenthesis represent assay response in mice.

* Human Thyrotrophin Research Standard A., Division of Biological Standards, National Institute for Medical Research Mill Hill, London, N.W. 7, England.

** Assay response of digested LATS-IgG $(5 \mathrm{mg})$.

*** Assay response of digested LATS-IgG $(25 \mathrm{mg})$.

All values are shown as mean \pm standard deviation.

Table 7. Thyroidal antibodies and serum gamma globulin in patients with high, LATS activity

\begin{tabular}{|c|c|c|c|c|c|c|c|}
\hline \multirow[b]{2}{*}{ Patient } & \multirow{2}{*}{$\begin{array}{c}\text { LATS } \\
\text { Activity }(\%)\end{array}$} & \multirow[b]{2}{*}{$\mathrm{TRC}^{1}$} & \multirow{2}{*}{$\begin{array}{l}\text { Antibody }{ }^{2} \text { to } \\
\text { cytoplasm }\end{array}$} & \multirow[b]{2}{*}{ Colloid } & \multicolumn{3}{|c|}{ Serum analysis $(\mathrm{mg} / \mathrm{m} l)$} \\
\hline & & & & & $\begin{array}{c}\text { Total }^{3} \\
\text { globulin }\end{array}$ & $\begin{array}{l}\text { Gamma } \\
\text { globulin }\end{array}$ & $\mathrm{IgG}^{5}$ \\
\hline T. V. & $1280 \pm 437$ & 40 & - & - & 36.5 & 16.0 & 12.2 \\
\hline S. H. & $1600 \pm 188$ & 2560 & +++ & ++ & 32.9 & 14.9 & 13.4 \\
\hline M. P. & $1450 \pm 279$ & 10 & - & - & 34.3 & 17.2 & 13.4 \\
\hline M. R. & $2000 \pm 278$ & 40 & - & - & 28.1 & 14.4 & 12.2 \\
\hline O. M. & $1338 \pm 42$ & 320 & + & - & 26.7 & 10.4 & 10.2 \\
\hline A. N. & $1433 \pm 333$ & 10 & - & - & 26.8 & 12.8 & 9.2 \\
\hline I. P. & $1048 \pm 56$ & 10 & + & - & 29.0 & 10.8 & 10.4 \\
\hline J. S. & $1320 \pm 220$ & 10 & - & - & 30.7 & 9.1 & 10.2 \\
\hline E. D. & $1450 \pm 279$ & 10 & + & - & 34.2 & 11.6 & 10.2 \\
\hline
\end{tabular}

1: Tanned red cell titers for anti-thyroglobulin are shown as inverse of titer.

2: Antibody to thyroidal antigen was determined by the immunofluorescent method.

3: Normal range, $25 \sim 35$.

4: Normal range, $8 \sim 12$.

5: Normal range, $8 \sim 12$. 


\section{Discussion}

LATS has been shown to be closely associated with the gamma-globulin fraction of serum-proteins (Dorrigton and Munro, 1966a; McKenzie, 1967). In our previous experiments and in the present study, LATS activity was neutralized by anti- $\gamma$-chain. All available evidence indicates that the thyroid stimulating activity is an inherent property of specific IgG molecules, although it remains difficult to prove that the activity may not be due to a small active fragment tightly bound to gammaglobulin.

The time course of ${ }^{125} \mathrm{I}$ release in the mouse bioassay following injection of TSH is different from that of LATS. Although McKenzie's paper (1966) shows that the assay response becomes prolonged type $(9 \mathrm{hr}>2 \mathrm{hr}$ ) by the injection of large amounts of TSH, in this experiment, large doses of TSH cause the assay response to become long acting $(8 \mathrm{hr}>2 \mathrm{hr})$ like LATS. This prolonged response does not continue for $24 \mathrm{hr}$, while the LATS response is present after $24 \mathrm{hr}$. The outstanding difference between LATS and TSH is obvious in the difference between the 8 and $24 \mathrm{hr}$ assay responses. These differences of response may be due to the disappearance rates of the two substances in blood. The half-life for disappearance from plasma of TSH is less than 20 $\mathrm{min}$ in the rat, but the half-life of LATS is 7 or $8 \mathrm{hr}$ (Adams, 1960).

EACA is known as an inhibitor of plasminogen activation, but also inhibits tissue reactions suspected to be allergic (tuberculin reaction) (Itoga and Yogo, 1959), immunohemolysis (Taylor and Fudenberg, 1964; Marschke and Tewksbury, 1966), precipitation of antigen-antibody (Atchley and Bhagavan, 1962; Auerswald and Doleschel, 1966), homograft rejection (Gillette et al, 1963; Bertelli et al, 1964), and anaphylaxic reactions (Zweifach et al, 1961). Also, Atchley and Bhagavan reported an inhibitory effect of EACA on the reaction of globulincoated nuclei with fluorescent anti-globulin conjugates. From these observations, it has been suggested that EACA does not inhibit the formation of antibodies, as cortisone, but rather has an effect on the antigen-antibody reaction. While the exact mode of the action is uncertain, inhibition of reactions between antigen and antibody may be due to specific relationships between the amino acid and the antigen-antibody complex (Atchley and Bhagavan, 1962). No effect of EACA was observed on the assay response to LATS. EACA is effective at plasma levels of more than 13 $\mathrm{mg} / 100 \mathrm{ml}$ (Council on Drugs, 1965). With 200 $\mathrm{mg}$ of EACA, all assay mice were killed, so 100 $\mathrm{mg}$ of EACA was used in each mouse, but the response to LATS was not suppressed. EACA did not inhibit the TSH response either. Cortisone had no effect on the response to LATS. McGiven et al (1965) reported that LATS was less stable to heat than TSH. In our experiment no clear difference between LATS and TSH could be found. It is interesting that the assay response to LATS still showed a "long acting type," in spite of a diminished thyroid stimulating activity due to partial denaturation of LATS molecule.

Beall and Solomon (1966b) showed that thyroid microsomes absorbed both LATS and TSH. Dorrington, et al. (1966b) observed that the thyroid microsomal fraction absorbed LATS, but could not demonstrate absorption of human TSH, either by thyroid homogenates or subcellular particles. Burke (1967) reported that the relationship between LATS and thyroid microsomes might be other than on an immunological basis. This position may be supported by the lack of a complement requirement in the LATS response, in contrast to other reactions of antibody with tissue particles (Beall and Solomon, 1966a; Kohler et al, 1967).

The absorption of LATS by thyroid microsomes was confirmed in our studies, but we could not detect an immunological reaction between LATS-IgG and solubilized thyroid microsome fraction. It is possible that thyroid 
tissue contains various enzymes destroying LATS activity, although the absorption of LATS is not affected by a number of enzyme inhibitors (Beall and Solomon, 1967). In another experiment, LATS activity was recovered following acid treatment of sedimented fractions after LATS-microsome incubation had been reported by Beall and Solomon (1966a). Now it is difficult to conclude the nature of the reaction between LATS and thyroid microsome.

A significant correlation in the decreased activity of LATS and TSH was observed following incubation with human thyroid microsomes. Human thyroid microsomes ( 5 to 10 $\mathrm{mg}$ ) inhibited LATS activity completely, while calf thyroid microsomes had less activity and at least $40 \mathrm{mg}$ of thyroid microsomes were necessary to inhibit it completely.

Thyroid stimulation by LATS was further investigated using subunits of the gammaglobulin. In the absence of reducing agents, the proteolysis of IgG with papain or pepsin yields a fragment with a sedimentation rate of approximately $5 \mathrm{~S}$, i. e., $\mathrm{F}(\mathrm{ab})_{2}$ and/or $\mathrm{F}\left(\mathrm{ab}^{\prime}\right)_{2}$. With reducing agents, papain or peptic digestion yields a $3.5 \mathrm{~S}$ fragment, $\mathrm{Fab}$ and $\mathrm{Fab}^{\prime}$. $\mathrm{F}(\mathrm{ab})_{2}$ and $\mathrm{F}\left(\mathrm{ab}^{\prime}\right)_{2}$ fragments (5S) are believed to have divalent antigen combining sites, and Fab and $\mathrm{Fab}^{\prime}$ fragments (3.5S) have univalent antigen combining sites (Kabat,1968). The present study suggests that thyroid stimulating actiaity of LATS-IgG may be in Fab or Fab'fragment, not in $\mathrm{Fc}$ fragment. Similar findings with peptic or papain digests of LATS-IgG were reported by Meek et al. (1964) and Dorrington et al. (1965).

These studies also indicate that fragments with divalent antigen binding sites show a prolonged response, and fragments with monovalent antigen binding sites produce a short acting response resembling TSH. Although LATS-IgG digested by papain (or pepsin) showed a prolonged response $(2 \mathrm{hr}<8 \mathrm{hr})$, these responses decreased to $30 \%$ of the $8 \mathrm{hr}$ level after $24 \mathrm{hr}$. (Table6) Thyroid stimulating action of these divalent fragments seems more prolonged than that of TSH, but shorter than that of intact LATS.

In human beings, the half-life of TSH in the blood is about $30 \mathrm{~min}$ (Bakke et al., 1962). The half-life of $\mathrm{F}\left(\mathrm{ab}^{\prime}\right)_{2}$ fragment obtained from pepsin digested piece is about $10-14 \mathrm{hr}$, and that of $\operatorname{IgG}$ is about 20 days (Janeway et al., 1968). Molecular size and the half-life of disappearance rate in the blood may play an important role in determining the time course of thyroid stimulation. The prolonged response induced by LATS might be explained by the prolonged stay of the substance in blood.

Until now the precise role of TSH and LATS at the cellular level is unknown and the difference in mode of action of these two substances is not clear. TSH and LATS have the same action on the release of thyroid hormone in guinea-pigs, mice and human beings, and may act as the same primary site on the thyroid gland in these animals. LATS does not stimulate the chicken thyroid gland (Lepp and Oliner, 1967). Although the chicken bioassay was less sensitive than the mouse, TSH (human and bovine) showed a stimulating effect as in the mouse bioassay, and the response was higher after $2 \mathrm{hr}$ than $8 \mathrm{hr}$, except with large doses. In our studies, the failure of LATS to stimulate the chick thyroid was confirmed. It is suggested by Lepp and Oliner that LATS might cause a response only in mammalian species, although TSH stimulated the thyroid of all animal species.

Fragments of digested LATS molecule were also inactive in the chicken thyroid gland. It is possible that $\mathrm{F}(\mathrm{ab})_{2}$ and $\mathrm{Fab}$ fragments, which may represent the active site of the molecule, cannot penetrate the cell membrane in chicken thyroid glands, because the molecular weight of $\mathrm{F}(\mathrm{ab})_{2}$ and $\mathrm{Fab}$ are 100,000 and 50,000 respectively, and these molecules are still larger than the TSH molecule.

The occurrence of LATS does not correlate with antibodies to thyroidal antigen, as shown previously (Ochi and DeGroot, 1968). Several patients having a high LATS activity had no antithyroglobulin titers or antibodies to cy- 
toplasm or colloid. In these sera, gammalgobulin and IgG were increased in only a few cases. The similar result was reported by Miyai (1968). From these observations, it appears that the LATS molecule has an extremely high specific activity.

This conclusion is also supported by our failure to identify thyroid tissue localization of LATS-IgG in the mouse thyroid after intravenous injection, or after application of LATS containing sera to human thyroid tissue. If LATS does combine with a thyroid antigen, the reaction must involve very small amounts of the gamma globulin.

\section{References}

Adams, D. D. (1960). Endocrinology 66, 658 Atchley, W. A. and N. V. Bhagavan (1962). Science 138, 528.

Auerswald, W. and W. Doleschel (1966). Brit. J. Exp. Path. 47, 525.

Bakke, J. K., N. Lawrence and S. Roy (1962). J. Clin. Endocrinol. 22, 352.

Beall, G. N. and D. H. Solomon (1966a). $J$. Clin. Endocrinol. 26, 1382.

Beall, G. N. and D. H. Solomon (1966b). $J$. Clin. Invest. 45, 552.

Beall, G. N. and D. H. Solomon (1967). Biochim. Biophys. Acta 148, 495.

Beall, G. N. and D. H. Solomon (1968). $J$. Clin. Endoirinol. Metab. 28, 503.

Bertelli, A., E. Bonmossar, E. Genovese, V. Lami, M. A. Rosane and E. Trabucchi (1964). Arch. Intern. Pharmacodyn 152, 189.

Burke, G. (1967). J. Clin. Endocrinol. 27, 1095

Council on Drugs (1965). J. Am. Med. Assoc. 191, 489.

Dorrington, K. J. and D. S. Munro (1966a). Clin. Pharm. and Therap. 7, 788.

Dorrington, K. J., L. Carneiro and D. S. Munro (1966b). J. Endocrinol. 34, 133.

Dorrington, K. J., L. Carneiro and D. S. Munro Current Topics in Thyroid Research, Cassano, C., and M. Andreoli, (eds), Academic Press, New York, p. 455 (1965).
Fagelman, D., B. McGhee and H. Chaplin, gr. (1966). J. Lab. and Clin. Med. 68, 445.

Gillette, R. W., A. Findley and H. Conway (1963). Transplantation 1, 116.

Itoga, G. and T. Yogo (1959). Keio J. Med. 8, 299.

Janeway, C. A., E. Merler, F. S. Rosen, S. Solomon and J. D. Crain (1968). New Engl. J. Med. 278, 919.

Kabat, E. A. Structural Concepts in Immunology and Immunochemistry Holt, Reinhart and Winson, Inc. p. 162 (1968).

Kohler, P. O., M. R. Mardiney and T. G. Ross (1967). Endocrinology 81, 671.

Lepp, A. and L. Oliner (1967). Ibid 80, 369.

Mandy, W. J. and A. Nisonoff (1963). J. Biol. Chem. 238, 206.

Marschke, G. R. and D. A. Tewksbury (1966). Ann. Allerg. 24, 610.

McGiven, A. R., D. D. Adams and H. D. Purves (1965). J. Endocrinol. 32, 29.

McKenzie, J. M. (1964). J. Clin. Endocrinol. 24, 660 .

McKenzie, J. M. and A. Williamson (1966). Ibid 26, 518.

McKenzie, J. M. (1967). Recent Progr. in Horm. Res. 23, 1.

McKenzie, J. M. (1968). J. Clin. Endocrinol. 28, 596.

Meek, J. C. A. E. Jones, U. J. Lewis and W. P. Vanderlaan (1964). Proc. Nat. Acad. Sc'. 52, 342.

Miyai, K. (1968). Acta Path. Jap. 18, 504.

Ochi, Y. and L. J. DeGroot (1968). Endocrinology 83, 845.

Ouchterlony, O. In Progress in Allergy, Karger, S. (ed.) Vol. 5 Basal and New York, p. 1 (1958).

Putnam, F. W., C. W. Easley and L. T. Lynn (1966). Biochim. Biophys. Acta 58, 279.

Sunshine, P., H. Kusumoto and J. P. Kriss (1965). Pediatrics 36, 869.

Taylor, F. B., Jr. and H. Fudenberg (1964). Immunol. 7, 319.

Zweifach, B. W., A. L. Nagler and W. Troll (1961). J. Exp. Med. 113, 437. 